\title{
Kilka uwag o trwałości legendy o krwi. Na marginesie Kłamstwa krwi Jolanty Żyndul
}

\author{
Joanna Tokarska-Bakir
}

\begin{abstract}
Abstrakt: Tekst jest rozszerzoną recenzją monografii historycznej dotyczącej legend o krwi ery nowoczesnej pióra Jolanty Żyndul. Historyczka odkrywa niezwykle liczne dziewiętnasto- i dwudziestowieczne przypadki obwinień Żydów o mord rytualny, zupełnie wyparte z pamięci historycznej Polaków. Sytuuje oszczerstwo krwi w sieci powiązań społecznych, religijnych i politycznych historii najnowszej, poddając rewizji narrację historyczną, która podważając znaczenie tych niezrozumiałych „epizodów”, wyprodukowała zapomnienie.

Wyrażenia kluczowe: legendy o krwi, żydowscy i nieżydowscy Polacy w XIX i XX wieku, Kościół katolicki, Narodowa Demokracja
\end{abstract}

Książka Jolanty Żyndul Kłamstwo krwi jest kolejnym opracowaniem naukowym poświęconym najnowszym dziejom legendy o tzw. żydowskim mordzie rytualnym, jakie w ostatnich latach ukazuje się na polskim rynku (Żyndul, 2011). Po Czarnej legendzie Hanny Węgrzynek (1995), Procesach o mordy rytualne w Polsce w XVI-XVIII w. Zenona Guldona i Jacka Wijaczki (1995) i Legendach o krwi niżej podpisanej (2008), z których każde wypełniało jakąś lukę tematyczną lub problemową, praca Żyndul skupia się na dziejach blood libel przede wszystkim w wieku XIX i XX, choć podejmuje też z konieczności „zadanie niemożliwe", zarysowując całą jego historię.

Słabo zbadana pod tym względem epoka, która stanowi przedmiot jej studiów, ma kluczowe znaczenie dla zrozumienia współczesnej debaty o tzw. antysemityzmie wtórnym. Autorka pisze:

„Między ostatnimi procesami o mordy rytualne w końcu XVIII w. i fantazjowaniem na temat uwięzienia Henryka Błaszczyka przez Żydów w Kielcach w 1946 r. legenda, nie dając o sobie znać aż tak silnie, wciąż była jednak żywa. Ta luka, dotycząca głównie przełomu XIX i XX wieku, powoduje, że pojawienie się wątku mordu rytualnego w historii powojennego antysemityzmu budzi wielkie zdziwienie. Chciałam pokazać, jakie czynniki umożliwiły przetrwanie legendy przez cały wiek XIX aż do powojennej eksplozji posądzeń, w jakich okolicznościach legenda powracała i co powodowało, że ulegała osłabieniu i zapomnieniu" (Żyndul, 2011, s. 9).

Książka ma ogromne znaczenie dla edukacji historycznej wykształconego czytelnika zainteresowanego polską przeszłością. Po roku 1989 w ramach rozmaitych polityk historycznych wytrwale zacierano ślady przedwojennego antysemityzmu, niepasujące do dominujących wyobrażeń. Ale jeszcze wcześniej, pod wpływem zerwania ciągłości pamięci spowodowanego wojną oraz pod naciskiem komunistycznej cenzury, ze świadomości historycznej zniknęła znaczna liczba polskich obwinień „o krew” z okresu międzywojnia, 
nie mówiąc o czasach starszych. Wizja „kraju bez stosów” została przejęta przez masową wyobraźnię w sposób, którego Janusz Tazbir zapewne by nie pochwalit. Ograniczmy się do dwóch przykładów: ocenzurowanie powojennego wydania dzieł Szymona Petrycego, z którego usunięto „litanię szkód”, wyrządzanych Rzeczpospolitej przez Żydów (Żyndul, 2011, s. 210) czy zatarcie antysemityzmu K. Cholewy de Pawlikowskiego, którego Polski słownik biograficzny przedstawia jako... autora „rozważań judaistyczno-religijnych” (Żyndul, 2011, s. 82). Badacz wrażliwy na położenie mniejszości poda ich z pewnością więcej. Autorkę niniejszych słów uderzyło na przykład, że jeszcze w latach osiemdziesiątych XX wieku pasjoniści katoliccy odsyłali czytelnika do książek księdza Stanisława Trzeciaka jako do poważnych źródeł „żydoznawczych”...

Kłamstwo krwi Jolanty Żyndul to książka tym ważniejsza, że w ostatnich latach właśnie z legendą o mordzie rytualnym łączy się szereg debat w naukach historycznych i społecznych. Pierwszą wywołał wniosek, który wprawdzie wysunęła już Krystyna Kersten, a następnie - w odniesieniu do pogromu krakowskiego - Anna Cichopek (Cichopek, 2000), jednak dopiero Marcin Zaremba odważył się wyraźnie go sformułować: poza jednym czy dwoma wyjątkami, wszystkie powojenne pogromy Żydów rozpoczynały się od pogłoski o porwaniu dziecka przez Żydów (Zaremba, 2007). Punktem numer dwa był spór dotyczący statusu legendy o krwi w pamięci współczesnych Polaków. Badania etnograficzne mojego zespołu na Sandomierszczyźnie, Podlasiu i w innych rejonach kraju (Tokarska-Bakir, 2008) ${ }^{1}$ wykazały znaczną aktywność wyobrażeń o tzw. żydowskich mordach krwi, co zaprzeczało dotychczasowym założeniom socjologów, przyjmującym, że legendy o krwi nie stanowią czynnika istotnego w obrazie współczesnych postaw antyżydowskich². W roku 2012 wyniki moich badań zostały inną metodą potwierdzone w tzw. reprezentatywnym badaniu ilościowym, przez Michała Bilewicza i Agnieszkę Haską, zakończonym konkluzją: „legenda mordu rytualnego wciąż pozostaje elementem nowożytnego antysemityzmu" (Bilewicz \& Haska, 2012). Tym samym została podważona zasadność wniosku o nieaktualności antysemityzmu religijnego (antyjudaizmu) dla kształtu współczesnych uprzedzeń antysemickich w Polsce ${ }^{3}$.

Antyjudaizm nie stracił na aktualności, ponieważ - co podkreślają tacy badacze, jak Sander L. Gilman i Steven Katz - stanowi nieprzemijającą matrycę nie tylko antysemityzmu, ale postaw wobec inności w ogóle. Niezależnie od tego, jak bardzo antysemityzm

1 Identyczne badania zostały następnie powtórzone przez zespół Archiwum Etnograficznego na Podlasiu hajnowsko-bielskim i łomżyńskim, na Zamojszczyźnie, na Lubelszczyźnie i w kilku innych rejonach kraju: Przedbórz, Rechta, Gniewczyna, Klimontów, okolice Lubelskich itd. Porównawczy raport ukaże się w roku 2014.

2 „Pytaliśmy także o aktualność wyobrażeń nazywanych przez G. Langmuira «stereotypami chimerycznymi», które przez wieki służyły do formułowania oskarżeń wobec Żydów [...] na czele z oskarżeniem o «rytualne zabójstwo». Pilotażowe badania wskazywały, że - jakkolwiek wciąż owe chimeryczne wyobrażenia są znane części badanych - nie można ich uznać za aktywne elementy stereotypowej, potocznej wiedzy o Żydach” (Krzemiński, 2004, s. 21).

3 Zob. też wypowiedź badacza Podlasia hajnowskiego: „W materiałach zebranych przeze mnie podział [antysemityzmu na nowoczesny i tradycyjny] jest zupełnie nieostry, a wątki wyodrębnione przez I. Krzemińskiego jako przynależne nowoczesnemu antysemityzmowi podawane są przez rozmówców za pomocą «języka religijnego»" (Buszko, 2012, s. 29). I dalej: „[...] w ostatnich latach ilość publikacji jawnie antysemickich, wychodzących z konserwatywnych kręgów prawosławnych, wyraźnie wzrasta, a pojęcie «mordu rytualnego» serwowane w tradycyjnie religijnym kontekście, często nabiera zupełnie nowych, odnoszących się do współczesności, lecz wciąż pozostających w kręgu mito-logiki, konotacji” (Buszko, 2012, ss. 115-116). Książka Buszki oparta jest na jego pracy magisterskiej pod tym samym tytułem, obronionej w roku 2007. 
dzisiejszy oddala się od swego religijnego prototypu, źródłem jego leksyki i rezerwuarem jego wyobrażeń było i zawsze pozostanie chrześcijaństwo. „Antysemityzm jest dla kultury Zachodu czymś absolutnie zasadniczym jako retoryka chrystianizacji kultury nawet w jej najbardziej świeckich odmianach. To sprawia, że utrwalony w ewangeliach negatywny obraz żydowskiej różnicy staje się głównym odniesieniem wszelkich określeń różnicy na Zachodzie" (Gilman \& Katz, 1991, s. 18). Tłumaczy to uderzające podobieństwo języków nienawiści, rasizmu, mizoginii i homofobii jako ukształtowanych na matrycy chrześcijańskiej opowieści o Antagoniście - wrogu Chrystusa.

Książka Jolanty Żyndul przynosi olbrzymi zasób lokalnego materiału historycznego tworzącego kontekst omawianych zjawisk. Oto konkluzja jednego z rozdziałów: „[...] antysemityzm, zbudowany na ideologii rasowej oraz na micie wszechpotęgi żydowskiej i międzynarodowego spisku żydowskiego, anektując dawno funkcjonujące antyżydowskie stereotypy w dziedzinie gospodarczej, nie zrezygnował też przynajmniej z części średniowiecznych przekonań, takich jak legenda mordu rytualnego" (Żyndul, 2011, s. 131). W XX wieku obserwujemy, jak ta ostatnia wchodzi w najbardziej zaskakujące sojusze, stając się już to elementem antysemityzmu lewicowego („kapitalistyczny żydowski krwiopijca”), już to propagandy antykomunistycznej („krwiopijcza żydokomuna”) (Janicka, 2008). Spektakularny przykład to przytaczana przez Żyndul wypowiedź Tadeusza Żywieckiego z „Pro Christo”, padająca w kontekście międzywojennych oskarżeń o mord rytualny: „Czyż wczoraj Rosja nie spłynęła krwią pomordowanych chrześcijan, zastrzelonych z ręki żydowskich komisarzy lub z ich rozkazu i w imię ich ideologii?" (Żyndul, 2011, s. 211; Janicka, 2011, s. $81 \mathrm{nn}$.). Ze swej strony dodam najnowsze zastosowanie zajmujących nas metafor: tytuł książki Henryka Pająka, Rytualna zemsta na kolebce „Solidarności”, 1981-2011 (Pająk, 2012).

\section{Społeczne uwarunkowanie wiedzy}

O tym, czym różni się tematyka książki Żyndul od innych problemów historycznych, można się było przekonać obserwując recepcję badanego przez nią zagadnienia w polskim polu naukowym. Badaczka przywołuje na wstępie niedawną konferencję poświęconą stereotypom narodowościowym, w czasie której „jeden z uczestników dyskusji - wywoŁując tym wielką burzę - stwierdził, że historyczne badania nad stereotypami, opisujące przecież treść tych stereotypów, przyczyniają się do ich wtórnego rozpowszechnienia" (Żyndul, 2011, s. 7). Autorka demaskuje bałamutny charakter podobnej argumentacji, która podaje się za anty-antysemicką, choć jej faktycznym celem jest zablokowanie krytyki antysemityzmu.

Zabieg oskarżania piętnującego antysemityzm o jego szerzenie, w angielskiej sferze językowej opisywany jako „strzelanie do posłańca, przynoszącego złe wieści”4, musi

4 Zob. Shooting the messenger („Shooting the messenger”, b.d.), gdzie odniesienie do Henryka IV Szekspira (akt I, scena 1, wers 95-103: „Thou shakest thy head and hold'st it fear or sin to speak a truth. [...] Yet the first bringer of unwelcome news hath but a losing office, and his tongue sounds ever after as a sullen bell, remember'd tolling a departed friend”) i Antoniusza i Kleopatry (akt I, scena 2: „The nature of bad news infects the teller”). Por. też cytat z Antygony Sofoklesa: „Bo nikt nie lubi złych nowin zwiastuna” (Sofokles, b.d.). 
zdumiewać w środowisku naukowym, jako że postulat utajnienia wyników badań popada w konflikt z elementarną etyką poznania: amicus Plato... („Amicus Plato, sed magis amica veritas", b.d.). Obwinianie uczonych, którzy przedmiotem swoich badań uczynili antysemityzm, o „nasilanie” go ma jednak długi żywot. We wstępie do książki Diabet i Żydzi (pierwodruk w 1943 roku) o podobnej argumentacji wspomina Joshua Trachtenberg: „Pewien bardzo szanowany duchowny niechcący zachęcił mnie do kontynuacji mych badań, argumentując, że to nieodpowiedni czas na przywoływanie do życia niemiłych wspomnień, jakie budzi mój temat. Po co rozgrzebywać te brudy w momencie takiego nasilenia antysemityzmu? A właśnie! Czy może być lepszy moment?" (Trachtenberg, 2011). Polscy zwolennicy poglądu o zależności między mówieniem o antysemityzmie i antysemityzmem - wśród nich można wymienić nie tylko ks. prymasa Józefa Glempa ${ }^{5}$, ale i niektórych socjologów ${ }^{6}$ - zdają się zapominać, że celem badań naukowych jest przede wszystkim ustalanie stanu rzeczy, a dopiero w dalszej kolejności (jeśli w ogóle) wpływanie na rzeczywistość.

Wielką wartością książki Jolanty Żyndul jest uprzytomnienie czytelnikowi, jak często podobne oczekiwania formułowano pod adresem studiów nad antysemityzmem, a także jaką rolę w utrwaleniu legend o krwi odegrały elity. „Środowiska narodowe wolały kwestię istnienia mordów rytualnych zostawić nierozstrzygniętą" (Żyndul, 2011, s. 188) - pisze Żyndul i ilustruje to wypowiedzią z „Przeglądu Katolickiego” z roku 1886: „ta forma fanatyzmu należy do przeszłości i dziś obawiać się jej już nie można. Lepiej więc zagrzebać ją w milczeniu niż wznawiać dysputami”. Autorka przekonująco objaśnia, co sprawiło, że w polskim dyskursie publicznym nigdy definitywnie nie rozstrzygnięto o nieprawdziwości legend o krwi. Wprawdzie paneuropejska afera związana z procesem Alfreda Dreyfusa (1894-1906) dotarła na ziemie rosyjskiej Polski (pisze o tym w niezwykle zajmującym artykule Antony Polonsky - Polonsky, 1997), ale w odróżnieniu od Francji, Niemiec czy Rosji lokalne kręgi intelektualne nie sformułowały żadnego listu ani w tej sprawie, ani w sprawie procesu Menachema Bejlisa (1913). Jeśli dodamy do tego słabość elit, zajętych raczej walką o niepodległość niż prawa obywatelskie, potęgę nauczania kościelnego, odwołującego się do Żywotów świętych księdza Skargi, tudzież lokalne kulty dzieci-męczenników, uzyskujemy w miarę pełną listę powodów trwania legendy. Przeciwstawiając się opinii Mariana Małowista, utrzymującego, że inteligencja polska opowiedziała się po stronie Bejlisa, Żyndul uważa, że materiał historyczny nie dostarcza na to dowodów (Żyndul, 2011, s. 188).

5 W okresie sporu o Karmel wyraził on pogląd, że ,jeśli nie będzie antypolonizmu, nie będzie u nas także antysemityzmu" (Forecki, 2010, s. 193-194, przyp. 113).

6 Ireneusz Krzemiński jeszcze w latach dziewięćdziesiątych przekonywał, że nagłaśnianie polskiego antysemityzmu „utrudnia Polakom wyznanie swoich win względem Żydów i osiągnięcie wzajemnego zrozumienia”. Uściślat, że to przede wszystkim „prożydowsko nastawione środowiska są skłonne szczególnie czarno i dramatycznie przedstawiać obraz antysemityzmu w naszym kraju”, czego dobrym przykładem może być „część Unii Wolności, zwłaszcza wywodząca się ze środowiska politycznego dawnego ROAD” (Krzemiński, 1996, s. 303). 


\section{Zmyślenie i prawda}

Autorka referuje to, co - poczynając od pierwszego europejskiego obwinienia o krew, przypadku Williama z Norwich (rok 1144), przez Hugona z Licolnu (rok 1255) i innych, aż po przypadek Szymona z Trydentu (rok 1475) - nazywane bywa „klasyczną legendą mordu rytualnego". Opiera się na badaniach uczonych, m.in. takich jak Po-chia Hsia i Allan Dundes, którego książka z 1991 roku pt. The Blood Libel Legend. A Casebook in Anti-Semitic Folklore uchodzi za jeden z najważniejszych - obok tomu pod redakcją księdza Stanisława Musiała i Stanisławy Buttaroni (Buttaroni \& Musiał, 2003) - zbiorów tekstów fachowych na ten temat (Dundes, 1991).

Właśnie od tego folklorystycznego akcentu chciałabym rozpocząć krytykę podejścia metodologicznego, które sprawia, że książka Żyndul, bardzo wartościowa w sensie faktograficznym, w sensie analitycznym nie do końca radzi sobie z tematem. Monumentalnej pracy Jolanty Żyndul trzeba oddać to, co się jej należy: docenić wysiłek pracy nad ogromnie rozległym i niewdzięcznym tematem, docieranie do trudno dostępnych źródeł, bezstronność i najwyższe standardy naukowe, sprawiające, że stanie się ona klasyczną pozycją w zakresie studiów nad wschodnioeuropejskimi „obwinieniami o krew”. Z antropologicznego punktu widzenia zasługuje ona jednak także na krytykę.

Wladimir Propp stwierdzit: „dopóki nie istnieje poprawne opracowanie morfologiczne [zagadnienia], dopóty nie może być właściwego opracowania historycznego" (Propp, 1976, s. 12), i to jest właśnie ten przypadek. Autorka pisze historię oskarżeń, układając ją w swoistą „historię naturalną" zjawiska ${ }^{7}$, jest natomiast bezradna, gdy chodzi o jego poprawną klasyfikację. W konsekwencji nie potrafi go teoretycznie „zoperacjonalizować” to jest dobrać właściwych narzędzi wyjaśniania jego trwałości.

O ile samo obwinianie Żydów o tzw. mord rytualny jest twardym faktem, potwierdzonym źródłami procesowymi, o tyle sam ów domniemany „rytualny aspekt morderstwa” jest, z czego autorka świetnie zdaje sobie sprawę, wymysłem, za pomocą którego starano się wyjaśnić niezrozumiałe zdarzenie (nieszczęśliwy wypadek, zaniedbanie rodzicielskie, akt pedofilii), po którym śladem są zwłoki albo zniknięcie dziecka. Do każdego przypadku trzeba dobrać osobną narrację i zastosować adekwatne narzędzia dekonstrukcji. Według terminologii Goethego, dzieje legendy to stop „zmyślenia i prawdy”. Nie można faktograficznie referować „zmyślenia”, nie przydając mu, poprzez sam historyczny format opowieści, pozorów „prawdy”, a taki właśnie efekt daje zastosowanie tradycyjnej narracji historycznej w opisie rzeczywistości gęsto przeplatanej legendą ${ }^{8}$. Aby posłużyć się zwięzłym sformułowaniem Sandera L. Gilmana: źródła dotyczące pomówień o krew należy czytać tropologicznie (analiza tropów i motywów), nie zaś chronologicznie. Dzięki niektórym partiom (np. rozdział VII) książka Kłamstwo krwi i tak stanowi wielki postęp

7 Thomas Kuhn przeciwstawiał podobną historię jej naukowemu opracowaniu (Kuhn, 1968, s. 32).

8 Temu tematowi poświęciłam wprowadzenie do moich Legend o krwi, gdzie szczegółowo analizuję wypowiedzi tych badaczy, którzy mimowolnie weryfikowali legendę (Tokarska-Bakir, 2008, s. 56). 
w stosunku do tradycyjnych prac na ten temat, z antropologicznego punktu widzenia jednak wciąż pozostawia wiele do życzenia.

Autorka powtarza, że zajmuje się legendami o tzw. żydowskim mordzie rytualnym, a więc przedmiotem etnograficzno-folklorystycznym, jednak nigdzie nie znajdziemy ani definicji legendy, ani mitu, ani kategorii myślenia magicznego. Tymczasem w etnografii istnieją dziesiątki znaczeń, do opisania których używa się powyższych kategorii, zaś ich ewolucja składa się na całą historię dyscypliny. Czy jest do pomyślenia sytuacja odwrotna, to znaczy taka, by etnograf, który wkracza w dziedzinę historyków, nie zdefiniował podstawowych kategorii analizy?

Legendy o krwi to przede wszystkim etnografia chrześcijan, a tylko w zakresie jej tragicznych skutków pewien aspekt historii Żydów. Ta hierarchia przedmiotowa rysuje się wyraźnie w dwóch książkach historycznych, których Jolanta Żyndul nie uwzględnia niestety w swojej bibliografii: w Gentiles Tales Miri Rubin (Rubin, 1999) i klasycznej The Jew and Human Sacrifice Hermanna Stracka (Strack, 1909). Sens pierwszej zawarty jest w jej tytule. Druga jest najlepszym znanym mi opracowaniem dotyczącym etnografii Żydów oraz chrześcijan, na podstawie którego można sobie wyrobić zdanie o tym, czyimi fantazjami były legendy o krwi. Pozostają w pamięci wypisy Stracka z dziewiętnastowiecznej prasy, która donosiła o sposobach, jakich chwytała się chrześcijańska ludność krajów niemieckich i słowiańskich w celu zdobycia ludzkiego tłuszczu na tzw. złodziejską świecę. W wyniku wierzenia, że wprawia ona okradanych w stan podobny do letargu, co pozwalało ich bez przeszkód okraść, z ręki kandydatów na złodziei w końcu XIX wieku musiało zginąć naprawdę sporo dzieci. Jeśli chodzi o trwałość innych wątków zanotowanych przez Stracka, jeszcze w roku 2005 zanotowałam na Sandomierszczyźnie wspomnienie o czarowniku, który w celach magicznych wykopywał żydowskie zwłoki („O takim, co rzucał uroki”, 2002, s. 22) ${ }^{9}$.

Jak autorka wzmiankuje na stronie 27, wśród obwinień o krew wiele było takich, w których wymyślano zarówno ofiary, jak i miejsce popełnienia mordu, nie mówiąc już o jego sprawcach. Wszystko tu odbywało się według pewnych reguł narracyjnych (w kategoriach folklorystyki Wladimira Proppa opisałam je w Legendach o krwi), skłaniających do fałszywego wnioskowania w oparciu o tzw. mocną empirię. Żyndul przytacza olbrzymi materiał potwierdzający tę tezę, ale nie widzi tych powtórzeń. Tymczasem jak pisze Miri Rubin, rytm i trajektoria oskarżeń Żydów o zbrodnie krwi są ściśle związane z legitymizacją, weryfikacją i prawomocnością kary za domniemane zbrodnie, innymi słowy z pytaniami, kto narrację o krwi inicjował, kto ją potwierdził i uwierzytelnił dokumentami z procesów, kronik, a współcześnie gazet odnotowujących pogrom. Rubin pisze: „Opowieść [o krwi] miała tak wielką moc i tak precyzyjnie określony cel, że ci, którzy ją głosili, uzyskiwali dzięki niej przywództwo i prawo do stosowania przemocy" (Rubin, 1999, s. 48). Gdy dzięki oskarżaniu Żydów można było zdobyć to prawo i przywództwo, koniunktura

9 Przekazy o magii owczarzy, wymagającej żydowskich zwłok, notuje też Oskar Kolberg. 
historyczna sprzyjała legendzie. Ten polityczny aspekt użytku z blood libel rzadko pojawia się w analizach Żyndul.

Autorka pisze: „Bezproblemowe włączenie do legendy mordu rytualnego ofiar w postaci młodych niezamężnych kobiet, które zajęły miejsce równorzędne z ofiarami dziecięcymi, podobnie jak pojawienie się nowego wzorca sprawcy, było możliwe dzięki zeświecczeniu legendy, która w akcie mordu rytualnego przestała widzieć powtórzenie Pasji Chrystusa" (Żyndul, 2011, s. 142). O ile zupełnie prawidłowe jest powiązanie nowego typu sprawcy i ofiar z narastającą ideologią narodową, o tyle ostatniej części wywodu autorki przeciwstawiłabym następującą wypowiedź Sandera L. Gilmana:

„Pogląd, że dziewiętnastowieczny antysemityzm rasowy czy też naukowy z powodu swojego przywiązania do ateizmu oznaczał radykalne zerwanie z religijną «średniowieczną» tradycją nienawiści do Żydów, wynika z niezrozumienia natury zeświecczenia tegoż modelu, zachodzącego w obrębie dziewiętnastowiecznych nauk biologicznych. [...] Ślepota i niezdolność Żydów do przyjęcia chrześcijaństwa stają się teraz ich «psychologicznym» ograniczeniem, uniemożliwiającym im pełną akulturację w zachodnim społeczeństwie. Wrodzona żydowska perfidia, wyrażająca się w ciągłym zdradzaniu Chrystusa na przestrzeni dziejów, staje się biologicznie zdeterminowaną cechą Żydów, która usposabia ich do odegrania bezdusznej roli w powstaniu kapitalizmu (lub komunizmu - do wyboru). Destrukcyjna rola Żydów wyrażająca się $w$ dosłownym odbieraniu życia chrześcijanom, czy to poprzez zbrodnie krwi, czy zatruwanie studni, prowadzące do epidemii Czarnej Śmierci, przekształca się w biologiczny udział Żydów w przenoszeniu chorób takich, jak syfilis [czy tyfus w propagandzie hitlerowskiej - przyp. JTB]" (Gilman \& Katz, 1991, s. 1).

Spór tych dwu stanowisk dotyczy tego, jak głęboko analizujemy wzór antyżydowskich wyobrażeń, gdzie widzimy ciągłość, a gdzie zerwanie. W ich prawidłowej lekturze bardzo pomogłaby historykom lekcja strukturalizmu antropologicznego.

\section{Reprodukcja legendy}

Charakterystyczny jest punkt wyjścia książki Jolanty Żyndul: „Chociaż świat naukowy już dawno uznał, że nie ma potrzeby powtarzać znanych argumentów, i żaden szanujący się historyk nie zaczyna swego tekstu o legendzie mordu rytualnego od stwierdzenia, że oskarżenie jest całkowicie bezpodstawne, wiele sygnałów z ostatnich lat wskazuje, że temat nie jest jeszcze zamknięty" (Żyndul, 2011, s. 8). Nasuwa się pytanie, czy postawa „szanujących się historyków” istotnie działa na rzecz „zamknięcia tematu”, czy raczej jest wyrazem bezradności wobec odradzającego się uparcie zjawiska. Czy badaczka, która ignoruje to pytanie, nie wikła się przypadkiem w sprzeczność z deklarowanym przez siebie zamiarem poszukiwania powodów trwałości przesądu o krwi? Bynajmniej nie chodzi o „powtarzanie znanych argumentów”, a raczej o szukanie nie tylko epistemologicznych przyczyn odradzania się legendy. 
To, jak funkcjonuje reguła kojarzenia dzieciobójstwa i Żydów w aktualnym polskim dyskursie publicznym, można pokazać na poniższym przykładzie. W roku $2008 \mathrm{w}$ jednym z dwóch najważniejszych polskich dzienników ukazała się następująca informacja:

„Przypadkiem wyszło na jaw, co robi sekta ortodoksyjnych żydów. 29-letni ultraortodoksyjny Żyd Elior Chen - nosi pejsy i chałat - stał na czele niewielkiej sekty, której siedziba znajdowała się w Jerozolimie. Wmówił swoim wyznawcom, że w małych dzieciach drzemią złe moce i najlepszym sposobem, żeby je wygnać, są wymyślne tortury. Szczegółowe instrukcje na ten temat wydawał na piśmie. Kazał zamykać dzieci w walizce na trzy dni, dźgać nożem. «Pracuję jako adwokat od 40 lat. Podczas całej mojej kariery nigdy nie słyszałem o czymś takim. To najstraszniejsza zbrodnia tego typu w historii Izraela» - powiedział «Rzeczpospolitej» znany jerozolimski prawnik Uri Huppert. Oto niektóre z metod «rabina»: bicie młotkiem, dźganie nożem i śrubokrętem, zmuszanie do jedzenia kału, zamykanie na trzy dni w walizce, biczowanie, przypalanie dłoni, lodowate prysznice, posypywanie ran solą, wpychanie do ust mycki i zaklejanie taśmą klejącą, wlewanie dzieciom alkoholu do gardła, dopóki nie zwymiotowały. Sprawa zapewne nigdy nie wyszłaby na jaw, gdyby «rabin» nie przeholował. Obrażenia jednego z dzieci okazały się tak poważne, że zawieziono je do szpitala. Lekarze natychmiast wezwali policję. To był straszliwy widok. Główka trzylatka była zmiażdżona, kora mózgowa odsłonięta. Dziecko przeżyło, ale do końca życia będzie w stanie wegetacji - powiedział inspektor Mickey Rosenfeld, rzecznik izraelskiej policji. Policjanci natychmiast pojechali do domu chłopca, gdzie znaleźli jego czteroletniego skatowanego braciszka. Okazało się, że w torturach brała udział ich matka, wyznawczyni Eliora Chena i jego kochanka w jednej osobie. Sam przywódca sekty uciekł do Brazylii i schronił się wśród tamtejszych ultraortodoksów. Chenowi za szczególne okrucieństwo wobec dzieci grozi od 10 do 15 lat więzienia. Jeżeli któraś z jego ofiar umrze, może zostać skazany na dożywocie. W Izraelu nie ma bowiem kary śmierci” („Zamykali dzieci na trzy dni w walizce i dźgali nożem”, 2008).

Informacja, powtórzona następnie przez polskie portale informacyjne, w tym „Wirtualną Polskę", stanowi klasyczną weryfikację legendy o krwi, namaszczoną przez gazetę mainstreamową. W kraju, w którym legenda ma podobną tradycję jak w Polsce, oznacza to jej reprodukcję i legitymizację. W połączeniu informacji o zwyczajnym przestępstwie z legendą o krwi, notatka z „Rzeczpospolitej” uruchamia wniosek: żydowski mord rytualny istnieje naprawdę. Przemilczaną przesłankę wnioskowania ${ }^{10}$, którą „audytorium samo, świadomie lub bezwiednie, wypełnia, aby dopełnić argumentację i uczynić ją koherentną" (Kurkowska-Budzan, 2009, s. 42), stanowi powiązanie żydowskości z dzieciobójstwem. O ile obwieszonych krzyżykami członków bandy Charlesa Mansona nie uważa się za chrześcijan, a członków sekty Asahary Shoko, który kilkakrotnie uzyskał błogosławieństwo Dalajlamy XIV, nie bierze za buddystów, inaczej będzie z żydami. W oczach kogoś, kto zna legendę o krwi, człowiek „w pejsach i chałacie” krzywdzący dziecko nie czyni tego jako człowiek, ale właśnie jako żyd.

10 Rozumowanie, w którym jedna z przesłanek jest przemilczana (domyślna), zwane jest przez Arystotelesa entymematem (Arystoteles, Retoryka I, 1; 1335a) albo sylogizmem skróconym. Entymemat może być silnym argumentem, gdyż ma zaletę zwięzłości i cechuje się często dużą siłą perswazyjną. „Skrót polega na opuszczeniu przesłanki [...]. To właśnie analiza entymematów pozwala na odsłonięcie ideologii, wartości, światopoglądu nadawcy, jak również odbiorcy" (Kurkowska-Budzan, 2009, s. 42; Ziomek, 2000). 
Winę za reprodukcję legend o krwi ponoszą nie tylko dziennikarze-sensaci. Przykładem badacza, który w ostatnich latach przyczynił się do niej szczególnie, jest ... naczelnik Oddziałowego Biura Edukacji Publicznej IPN w Rzeszowie, autor książki Pogrom, którego nie było (Kaczmarski, 2008b), poświęconej pogromowi w Rzeszowie (Jolanta Żyndul wspomina tę książkę, ale jej nie komentuje). Monografię, będącą w głównej mierze edycją przerażających źródeł z roku 1945, autor kończy zdaniem: „zebrane w toku [śledztwa] poszlaki wskazują, że zabójcą mógł być któryś z żydowskich lokatorów kamienicy przy al. Tannenbauma 12, gdzie wieczorem 11 czerwca znaleziono zwłoki Bronisławy Mendoń i gdzie - najprawdopodobniej cztery dni wcześniej - została ona zgwałcona i zamordowana" (Kaczmarski, 2008b, s. 57). Kilka stron dalej naczelnik Biura Edukacji Publicznej przytacza bez komentarza kuriozalną opowieść proboszcza, ks. Szteli, który z kolei przekazuje to, co mówiła mu parafianka. Była ona krytycznego dnia w kamienicy przy ul. Tannenbauma.

„Mąż zamówił u Żyda przy dzisiejszej ulicy Okrzei [d. Tannenbauma] wódkę na wesele. Wesele miało być w sobotę, więc wcześniej przyszły mąż powiedział: Idź do Żyda po tę wódkę. Poszła. A tam zamknięte. I słychać jakieś granie. Takie rytmiczne, przejmujące. I śpiew. Też niezwykły. Pukała. Nikt nie odmykał. Drugi raz poszła wieczorem. Znów słyszała to granie przez zamknięte drzwi. Gdy tak stała przy drzwiach i pukała, wyszła dozorczyni i powiedziata: czego tu chcesz? Uciekaj dziewczyno, tu się straszne rzeczy dzieją. Ty nie wiesz, gdzie przychodzisz" (Kaczmarski, 2008b, ss. 60-61, przyp. 4) ${ }^{11}$.

Na skutki książki Krzysztofa Kaczmarskiego, który swoje wnioski („zabójcą mógł być któryś z żydowskich lokatorów kamienicy przy Tannenbauma 12") upowszechniał zarówno w „Radiu Maryja” (Kaczmarski, 2008a), jak i w „Naszym Dzienniku” (Kaczmarski, 2009), natknęłam się w czasie ekspedycji terenowej na Zamojszczyźnie w roku 2009. Rozmówczyni, spotkana przez uczestniczkę badań na przystanku autobusowym, powoływała się na artykuł w lokalnej gazecie, z którego wynikało jej zdaniem, że IPN udowodnił, że „mordy rytualne istniały naprawdę"12. Wniosek można składać na karb naiwnej lektury, trudno jednak uwierzyć w to, że zasmuci on autora książki, bywalca klubów ONR-u i Młodzieży Wszechpolskiej, reklamującego się także na stronach nacjonalista.pl i narodowcy.net ${ }^{13}$.

Wnioski? Ponieważ głos historyków w Polsce wciąż uważa się za najbardziej prawomocny, jest niezmiernie ważne, by byli oni świadomi spoczywającej na nich odpowiedzialności. Świadomy historyk powinien referować fakty, a powstrzymywać się od spekulacji, ta bowiem natychmiast wikła go w potężnie oddziałujący kontekst pozanaukowy, w tzw. społeczne uwarunkowanie wiedzy ${ }^{14}$.

\footnotetext{
11 Fragment ten, w książce Kaczmarskiego cytowany na s. 60-61 przyp. 4, w całości opublikowany został na stronie polonijnej: http://www.kuriercodziennychicago.com/szczepanski-jestemantysyjonista.html (dostęp 30.8.2011).

12 Relacja Agnieszki Kozik, 2008. Artykuł autorstwa Jaromira Kwiatkowskiego, zatytułowany Czy Bronkę zamordowali rzeszowscy Żydzi?, opublikowano w dzienniku „Nowiny” (Kwiatkowski, 2009).

13 Odpowiednio, np. http://www.nacjonalista.pl/tagi/krzysztof-kaczmarski/; http://forum.narodowcy.net/viewtopic. php? $\mathrm{f}=5 \& \mathrm{t}=76 \&$ start $=20$

14 W Legendach o krwi analizowałam te ryzykowne konteksty na przykładzie wypowiedzi Hanny Węgrzynek i Krzysztofa Lewalskiego (Tokarska-Bakir, 2008, ss. 86-94).
} 
Ma to też swoje uzasadnienie metodologiczne. Nauki aspirujące do miana „nauki normalnej" zwykły formułować swoje wypowiedzi tylko w odniesieniu do pewnej, jak to określa Thomas Kuhn, specyficznej „klasy faktów”. Gdyby zaadaptować pojęcie nauki normalnej na użytek historii, powiedzielibyśmy, że nie powinna się ona zajmować tym, co mogło się zdarzyć, bo to nie jest sprawdzalne, a nadto prowadzi do operowania nierzeczywistymi okresami warunkowymi, to jest zdaniami typu: „co byłoby, gdyby”. Nadto można zauważyć, że z logicznego punktu widzenia nie dowodzi się zdań negatywnych, na przykład, że coś nie istnieje ${ }^{15}$.

Ludzie, którzy słyszą, że nie udowodniono historyczności ani jednego obwinienia o krew, pytają zazwyczaj: „czy to znaczy, że podobna rzecz nie mogła się wydarzyć?”. Niestety, nie jest to przedmiot badania historycznego - nie można udowodnić, że czegoś nigdy nie było. Obrazowo wykłada ten paradoks Hermiona, bohaterka cyklu powieści Joan Rowling, mówiąc o kamieniu nieśmiertelności: „Niby jak mam udowodnić, że on nie istnieje? Co, może mam brać po kolei do ręki wszystkie kamyki świata, żeby każdy wypróbować? W ten sposób można dowodzić istnienia czegokolwiek, jeśli jedyną podstawą wiary, że coś istnieje, jest niemożność udowodnienia, że to coś nie istnieje" (Rowling, 2012, ss. 425-426). Jedno jest pewne: historycy, którzy nie będąc w stanie udowodnić niemożliwości, wypowiadają się o możliwości popełnienia przez Żydów mordów rytualnych, poważnie obciążają swoje sumienie.

\section{Myślenie magiczne i nowoczesny antysemityzm}

W mojej pracy nad tematem legendy o krwi zasadnicze znaczenie miał moment, gdy przeczytałam zdanie Georga Schroubka: „Wysuwane od XII wieku przez chrześcijan oskarżenia o zbrodnie krwi uważa się chętnie za rezultat głupich «przesądów ludu». W rzeczywistości wiążą się one ściśle z subtelnymi teologicznymi rozważaniami, prowadzonymi w późnym średniowieczu na temat Męki Pańskiej, eucharystii, pobożności i nauki o transsubstancjacji" (Schroubek, 2003, s. 157). Pogląd Schroubka można zastosować do całych dziejów legendy o krwi. Przechowuje ją tzw. lud, ale to nie „lud” ją wymyślit. Jak wiele innych, jest ona rezultatem opadania treści kulturowych. Przez wieki podtrzymywały ją elity - nie tylko duchowieństwo, ale też lekarze, sporządzający obdukcje ciał dzieci i doszukujący się charakterystycznych obrażeń odwzorowujących bogobójstwo, dziennikarze piszący sensacyjne artykuły, nie dość ostrożni naukowcy i historycy. Prowadzi nas to do istotnej dyskusji, jaką Jolanta Żyndul podejmuje z Marcinem Zarembą w związku z tym, że we wszystkich polskich pogromach powojennych (z wyjątkiem m.in. Przedborza i Starachowic) iskrę stanowiła legenda mordu rytualnego.

Zaremba pisze (podążam za streszczeniem jego poglądów przez Jolantę Żyndul), że „mit mordu rytualnego odsuwał poczucie winy, odnawiał autostereotyp bohaterskiego i cierpiącego Polaka, przywracał ład moralny dzięki wskazaniu, że Żydzi są winni,

15 Dziękuję prof. Janowi Woleńskiemu za konsultację powyższej kwestii. 
a prawdziwymi bohaterami są Polacy” (Żyndul, 2011, s. 234) ${ }^{16}$. Powszechna wiara w legendę nie byłaby jednak, jego zdaniem, możliwa bez regresu cywilizacyjnego „do epoki przedgutenbergowskiej" i czerpania głównie z przekazu ustnego wobec braku wiarygodnych środków masowego przekazu. Zgadzając się z analizą Zaremby, Żyndul słusznie kwestionuje postrzeganie legendy jako przejawu magicznego myślenia, charakterystycznego dla ludzi religijnych i słabo wykształconych, któremu sprzyjają przekaz ustny i plotka. Zwraca uwagę na znaczenie masowej prasy w jej rozpowszechnieniu w wieku XX. Pisze też, że legenda mogła funkcjonować w nowoczesnych czasach tylko dlatego, że ten magiczny rdzeń został przesunięty na dalszy plan, czego przykładem jest jej „racjonalizacja”, wprowadzenie pogłoski o transfuzjach oraz zastąpienie kategorii „dzieci chrześcijańskie” kategorią „dzieci polskie”.

Uwagi Jolanty Żyndul są słuszne i ważne, jednak z pewnymi zastrzeżeniami. Przejście od terminologii religijnej do narodowej (a następnie lewicowej!) szczegółowo zanalizowałam w artykule Figura Krwiopijcy $w$ dyskursie religijnym, narodowym i lewicowym Polski w latach 1945-1946. Studium z antropologii historycznej (Tokarska-Bakir, 2010, 2012), z którym autorka zapewne nie zdążyła się już zapoznać. Na uznanie zasługuje jednak jej spostrzegawczość w kwestii obiegów kulturowych, w jakich rozprzestrzeniała się legenda, i sugestia, że jej adresatami wcale nie były tylko osoby „religijne i słabo wykształcone". Od wieku XIX dla przetrwania i wtórnego rozpowszechnienia legendy coraz większe znaczenie miała prasa i literatura popularna, a także wspominany „czynnik racjonalizacji”, czyli zamazywania magicznego charakteru pogłoski. Jednak zarówno Jolanta Żyndul, jak i Marcin Zaremba błędnie rozumieją pojęcie „racjonalizacji”" ${ }^{17}$, co wynika z zatarcia zaledwie imitującego racjonalność charakteru procedury i ze zbyt ostrego rozgraniczania „myślenia racjonalnego” i „magicznego”. W etnografii co najmniej od czasów krytyki Luciena Levy-Bruhla, autora pojęcia „myślenie prelogiczne”, nie uważa się ich za wykluczające się style poznawcze, tylko za sąsiadujące ze sobą na równych prawach tendencje, które można rozpoznać u wszystkich, nawet najbardziej wykształconych ludzi. „W każdym z nas drzemie dziecko, mówi w skrócie Van Gennep" - pisze Jeanne Favret-Saada (Favret-Saada, 2012, s. 341). Na przykładzie transmisji legendy mordu rytualnego widać, jak fałszywe jest też przeciwstawienie myślenia magicznego jako domeny przekazu ustnego (plotki) myśleniu racjonalnemu „epoki gutenbergowskiej” (prasa i książka). Czyniący to historycy nie biorą pod uwagę, że to właśnie druk, a konkretnie pierwszy drukowany bestseller, jakim była Kronika świata Hartmanna Schedla (wydana w 1493 roku) zawierająca drzeworyt, przedstawiający scenę mordu rytualnego $\mathrm{w}$ Trydencie, był najpotężniejszym kanałem rozpowszechniania legendy o krwi w jej apogeum.

16 „Mit ucieleśniał społeczne lęki i je kanalizował. Wskazując na zagrożenie, ułatwiał z nim walkę. Był formą artykulacji lęku i wrogości. Teraz wystarczyło usunąć Żydów, by przestać się bać. Na tym polegała społeczna funkcja mitu mordu rytualnego" (Zaremba, 2007, s. 128).

17 Zob. np. definicja racjonalizacji w psychoanalizie: „Procedura, przez którą podmiot usiłuje nadać spójne z punktu widzenia logiki lub możliwe do przyjęcia z punktu widzenia moralnego wyjaśnienie jakiejś postawy, działania, myśli, uczucia itp., których prawdziwe motywy nie są postrzegane” (Laplanche \& Pontialis, 1996, s. 275). 


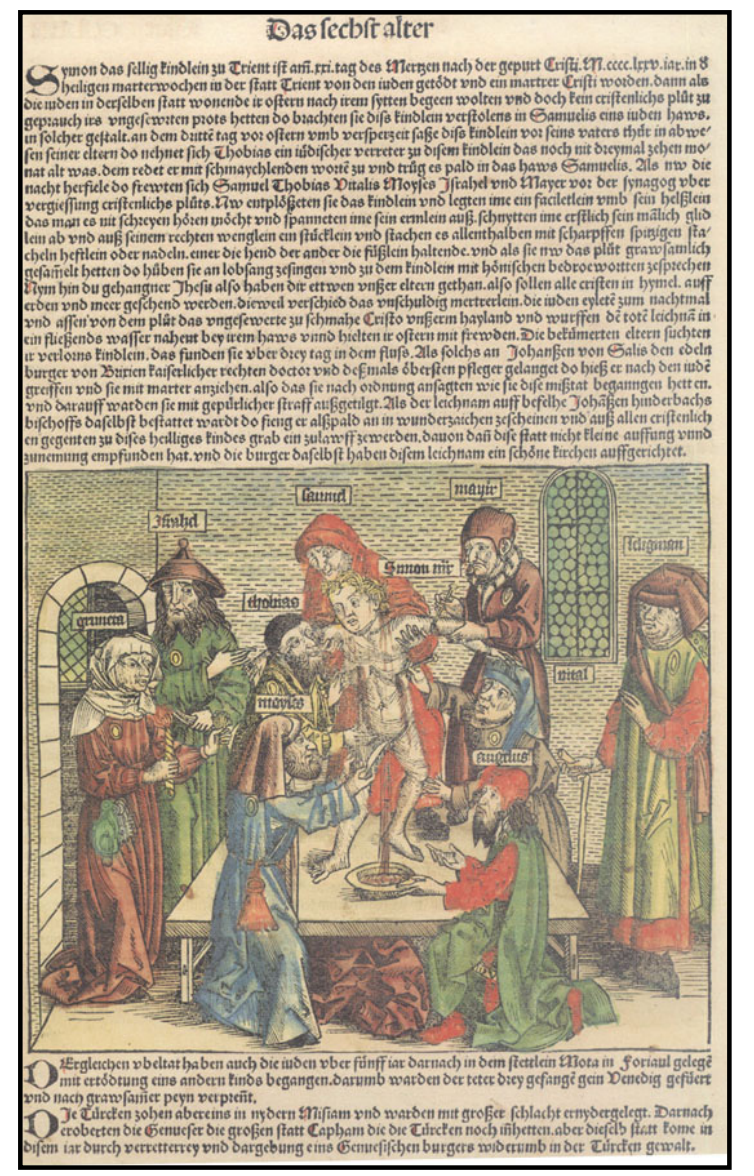

Drzeworyt przedstawiający żydowskich sprawców domniemanego mordu rytualnego na Szymonie z Trydentu w roku 1475, Kronika świata Hartmanna Schedla; wg http://en.wikipedia.org/wiki/File:Schedel_judenfeindlichkeit.jpg

Doprawdy łatwo jest obwiniać „ciemny lud”, znacznie trudniej zauważyć go w świecie namaszczonych elit, w identyczny sposób jak on podlegających pokusom irracjonalności i społecznemu ciśnieniu. Świat nie dzieli się, jak chcieli ewolucjoniści, od których rozpoczęła się historia etnografii, na ludzi myślących magicznie i oświeconych. Jest to podział fałszywy i niebezpieczny, bo „im bardziej tamci są godni potępienia, tym mniej powodów do niepokoju mamy my" (Bauman, 1991, s. 15).

\section{Kilka korekt}

Na koniec chciałabym dorzucić uwagę częściowo osobistą. Jest mi trudno wypowiadać się o książce Jolanty Żyndul, choć dotyczy tematu, któremu i ja poświęciłam monografię opublikowaną w roku 2008. Autorka napomyka o niej, a jednocześnie w pewien sposób jej „nie widzi”. Nie musi podzielać mojego stanowiska, mogłaby jednak podjąć polemikę, tym bardziej, że ceni autorów, którzy podobnie jak ja podążają za hipotezą projekcji jako źródła chrześcijańskich legend o krwi. Najważniejszym jej zwolennikiem był cytowany przez Żyndul folklorysta Allan Dundes. Wyłożył ją w tekście zatytułowanym The Ritual Murder or Blood Libel: A Study of Anti-Semitic Victimization through Projective Inversion (Dundes, 2007, ss. 386-409), w którym stawia tezę, że legenda o krwi jest zagadnieniem 
źle badanym, nie stanowi bowiem problemu historycznego, tylko psychologiczny: „Projective inversion refers to a psychological process in which $A$ accuses $B$ of carrying out an action which A really wishes to carry out him or herself". Dodam, że hipoteza projekcyjna jest dużo starsza niż sądzi Żyndul, sięga bowiem czasów przedwojennych, gdy wysunął ją jezuita, Peter Browe ${ }^{18}$.

Poniżej kilka innych przykładów nawiązań, które wzmocniłyby własną argumentację autorki Kłamstwa krwi. W roku 2008 wraz z moim Archiwum Etnograficznym prowadziłam badania na Podlasiu hajnowsko-bielskim, dotyczące m.in. kultu Gabriela Zabłudowskiego, zakończone raportem i filmem Aleksandry Wróblewskiej Wędrówka Gabriela. Premiera odbyła się w Fundacji Batorego, a w dyskusji brała udział Jolanta Żyndul (Wędrówka Gabriela. Religia i antysemityzm, 2009). Nie mogę zrozumieć, dlaczego nie wspomina ani przedstawionych wówczas wyników moich badań [uczestnikom rozdano raport, następnie opublikowany (Tokarska-Bakir, 2009, ss. 35-94)], ani samego filmu. Z innych drobiazgów: omawiając twórczość K. Cholewy de Pawlikowskiego autorka pisze, że „nigdy nie została [ona] poddana analizie krytycznej, zapewne dlatego że publikował po niemiecku". Zmieniłaby zdanie, gdyby sięgnęła do Legend o krwi (Tokarska-Bakir, 2008, ss. 82-86). Gdyby zajrzała tam na stronę 392, znalazłaby czeską piosenkę ilustrującą domniemany mord rytualny na Anežce Hrůzovej (z 1899 roku), a na stronach 302-318 - dzieje domniemanej profanacji poznańskiej (z 1399 roku). Na stronach 67-68 natrafiłaby na dyskusję historii pojęć, jakimi opisywano legendę o krwi, a na stronie 67 na omówienie zagadnienia autorstwa Zapiski o ritualnych ubijstwach przypisywanej W. I. Dalowi. W apendyksie do mojej książki znalazłaby wydany przez Tomasza Płóciennika duży wybór dokumentów z Archiwum Diecezjalnego w Sandomierzu dotyczący procesu Żydów sandomierskich z lat 1710-1712, a także oskarżającego ich konwertyty, Jana Serafinowicza (Tokarska-Bakir, 2008, ss. 694-714), o którym się rozpisuje. Po co powoływać się w bibliografii na książkę, skoro nie korzysta się z zawartego w niej aparatu naukowego i źródeł?

\section{Bibliografia}

Amicus Plato, sed magis amica veritas. (b.d.). wikipedia.en. Pobrano z http://en.wikipedia.org/wiki/ Amicus_Plato,_sed_magis_amica_veritas

Bauman, Z. (1991). Nowoczesność i Zagłada. (F. Jaszuński, Tłum.). Warszawa: Fundacja Kulturalna Masada.

Bilewicz, M., \& Haska, A. (2012, październik 1). Wiara w mord rytualny we współczesnej Polsce (raport). Otwarta Rzeczpospolita. Pobrano z http://www.otwarta.org/index.php/kto-wierzy-w-mord-rytualny/

Buszko, P. (2012). Żyd „Żydem”. Wizerunek Żyda w kulturze ludowej podlaskich prawosławnych Białorusinów. Miasteczko Orla. Warszawa: Instytut Slawistyki PAN.

Buttaroni, S., \& Musiał, S. (Red.). (2003). Mord rytualny: legenda w historii europejskiej. (R. Brandstätter, Tłum.). Kraków, Norymberga, Frankfurt/M.: Stowarzyszenie na Rzecz Inicjatyw Kulturalnych.

Cichopek, A. (2000). Pogrom Żydów w Krakowie 11 sierpnia 1945. Warszawa: Żydowski Instytut Historyczny.

18 W Legendzie krwi piszę, że jego zasługi przybliża Kenneth Stow (Stow, 2006, s. 120 nn.). Browe uważał, że legendy o krwi opierają się na projekcji, bowiem grzechy chrześcijan zostały w nich przypisane Żydom (Stow, 2006, s. 120, przyp. 3).

SLH 2/2013 | str. 295 
Dundes, A. (Red.). (1991). The Blood Libel Legend. A Casebook in Anti-Semitic Folklore. Madison: University of Wisconsin Press.

Dundes, A. (2007). The Ritual Murder or Blood Libel: A Study of Anti-Semitic Victimization through Projective Inversion. W S. J. Bronner (Red.), The Meaning of Folklore. The Analytical Essays of Alan Dundes (ss. 386-409). Logan: Utah State University Press.

Favret-Saada, J. (2012). Śmiercionośne słowa, zabójcze uroki. (K. Marczewska, Tłum.). Warszawa: Oficyna Naukowa.

Forecki, P. (2010). Od „Shoah” do "Strachu”. Spory o polsko-żydowską przeszłość i pamięć w debatach publicznych. Poznań: Wydawnictwo Poznańskie.

Gilman, S. L., \& Katz, S. T. (1991). Preface. W S. L. Gilman \& S. T. Katz (Red.), Anti-Semitism in Times of Crises. New York: New York University Press.

Janicka, E. (2008). Mord rytualny z aryjskiego paragrafu. O książce Jana Tomasza Grossa „Strach. Antysemityzm w Polsce po wojnie. Historia moralnej zapaści”. Kultura i Społeczeństwo, 52(2), 229-252.

Janicka, E. (2011). Festung Warschau. Warszawa: Wydawnictwo Krytyki Politycznej.

Kaczmarski, K. (2008a). Pogrom, którego nie było. radiomaryja.pl. Pobrano z http://www.radiomaryja.pl/ bez-kategorii/pogrom-ktorego-nie-bylo/

Kaczmarski, K. (2008b). Pogrom, którego nie było. Rzeszów 11-12 czerwca 1945 r. Fakty hipotezy dokumenty. Rzeszów: IPN.

Kaczmarski, K. (2009, luty 28). Pogrom, którego nie było. Nasz dziennik.pl. Pobrano z http://www.naszdziennik.pl/index.php?dat=20090228\&typ=kl\&id=kl11.txt

Krzemiński, I. (Red.). (1996). Czy Polacy są antysemitami? Wyniki badania sondażowego. Warszawa: Oficyna Naukowa.

Krzemiński, I. (Red.). (2004). Antysemityzm w Polsce i Ukrainie. Raport z badań. Warszawa: Wydawnictwo Naukowe Scholar.

Kuhn, T. (1968). Struktura rewolucji naukowych. (H. Ostromęcka, Tłum., S. Amsterdamski, Red.). Warszawa: PWN.

Kurkowska-Budzan, M. (2009). Antykomunistyczne podziemie zbrojne na Białostocczyźnie. Analiza współczesnej symbolizacji przeszłości. Kraków: Towarzystwo Wydawnicze „Historia lagellonica”.

Kwiatkowski, J. (2009, marzec 13). Czy Bronkę zamordowali rzeszowscy Żydzi? nowiny24. Pobrano z http://www.nowiny24.pl/apps/pbcs.dll/article?AID=/20090313/WEEKEND/526372346

Laplanche, J., \& Pontialis, J. B. (1996). Stownik psychoanalizy. (E. Modzelewska \& E. Wojciechowska, Ttum.). Warszawa: Wydawnictwa Szkolne i Pedagogiczne.

O takim, co rzucał uroki. (2002). Ożarów. Samorządowe pismo społeczno-kulturalne, (12).

Pająk, H. (2012). Rytualna zemsta na kolebce „Solidarności”. Lublin: Retro.

Polonsky, A. (1997). The Dreyfus Affair and Polish-Jewish Interaction, 1890-1914. Jewish History, 11(2), 21-40.

Propp, V. (1976). Morfologia bajki. (W. Wojtyga-Zagórska, Tłum.). Warszawa: Książka i Wiedza.

Rowling, J. K. (2012). Harry Potter i insygnia śmierci. (A. Polkowski, Tłum.). Poznań: Media Rodzina.

Rubin, R. (1999). Gentile Tales. The Narrative Assault on Late Medieval Jews. New Haven, New York: Yale University Press.

Schroubek, G. (2003). Zagadnienie historyczności postaci Andrzeja z Rinn. W S. Buttaroni \& S. Musiał (Red.), Mord rytualny: legenda w historii europejskiej. Kraków, Norymberga, Frankfurt/M.: Stowarzyszenie na Rzecz Inicjatyw Kulturalnych.

Shooting the messenger. (b.d.). Wikipedia.en. Pobrano z http://en.wikipedia.org/wiki/Shooting_the_messenger 
Sofokles. (b.d.). Antygona. (K. Morawski, Tłum.). wolnelektury.pl. Pobrano z http://wolnelektury.pl/media/ waiter/book/antygona/antygona-custom--4283367457733687156.pdf

Stow, K. (2006). Jewish Dogs. An Image and Its Interpreters. Continuity in the Catholic-Jewish Encounter. Stanford: Stanford University Press.

Strack, H. (1909). The Jew and Human Sacrifice. Human Blood and Jewish Ritual. An Historical and Sociological Inquiry. (H. Blanchamp, Tłum.). London: Cope \& Fenwick.

Tokarska-Bakir, J. (2008). Legendy o krwi. Antropologia przesądu. Warszawa: W.A.B.

Tokarska-Bakir, J. (2009). Raport z badań podlaskich 2007. Societas/Communitas, (2), 35-94.

Tokarska-Bakir, J. (2010). Figura Krwiopijcy w dyskursie religijnym, narodowym i lewicowym Polski w latach 1945-1946. Studium z antropologii historycznej. Sprawy Narodowościowe SN, 37, 19-48.

Tokarska-Bakir, J. (2012). Figura Krwiopijcy w dyskursie religijnym, narodowym i lewicowym Polski w latach 1945-1946. Studium z antropologii historycznej. W J. Tokarska-Bakir, Okrzyki pogromowe. Szkice z antropologii historycznej Polski lat 1939-1946 (ss. 113-141). Wołowiec: Czarne.

Trachtenberg, J. (2011). Diabeł i Żydzi: średniowieczna koncepcja Żyda a współczesny antysemityzm. (R. Stiller, Tłum.). Kraków: Wydawnictwo Vis-à-vis/Etiuda.

Wędrówka Gabriela. Religia i antysemityzm. (2009). Pobrano z http://www.batory.org.pl/aktualnosci/ zapis_debaty_wedrowka_gabriela_religia_i_antysemityzm

Zamykali dzieci na trzy dni w walizce i dźgali nożem. (2008, czerwiec 6). Rzeczpospolita.

Zaremba, M. (2007). Mit mordu rytualnego w powojennej Polsce. Archeologia i hipotezy. Kultura i Spoteczeństwo, 51(2), 91-135.

Ziomek, J. (2000). Retoryka opisowa. Wrocław: Zakład Narodowy im. Ossolińskich.

Żyndul, J. (2011). Kłamstwo krwi. Legenda mordu rytualnego na ziemiach polskich w XIX i XX wieku. Warszawa: Wydawnictwo Cyklady.

\section{A few remarks on the persistence of the legend of blood}

Abstract: The article is an extended review of Jolanta Żyndul's Kłamstwo krwi ('The Lies of Blood'). Żyndul unearths numerous cases of accusing Jews of ritual murders, which happened in the 19th and the 20th century, and were then forgotten by the Poles. Żyndul puts the libel of the legend of blood inside a wider context of social, religious and political relations in the recent history. She revises the historical narration, which produced the oblivion by undermining the significance of those events.

Keywords: blood legends, Jewish Poles and non-Jewish Poles in the 19th and 20th century, Roman Catholic Church, Narodowa Demokracja 